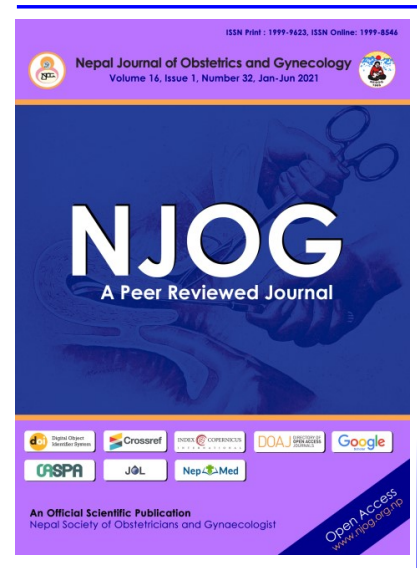

CORRESPONDENCE

Dr Munjal Yadav

Department of OBGYN, Nobel Medical College

Teaching Hospital, Biratnagar, Nepal

Email:moonzal13688@gm ail.com;

Phone: +977-9860435531

Received: April 15, 2021

Accepted: May20, 2021

\section{Citation:}

Yadav M. Baral G. Maternal and perinatal outcome in Rh-Negative women. Nep J Obstet Gynecol. 2021;16(32):108-110. DOI: https:// doi.org/10.3126/ njog.v16i1.37619

\title{
Maternal and perinatal outcome in Rh-Negative women
}

\author{
Munjal Yadav, Gehanath Baral \\ Nobel Medical College Teaching Hospital, Biratnagar, Nepal
}

\section{ABSTRACT}

Aim: To find out the Maternal and perinatal outcomes in $\mathrm{Rh}$-Negative mothers.

Methods: This is a cross sectional study of all Rhesus negative mothers giving childbirth at Department of Obstetrics and Gynecology, Nobel Medical College Teaching Hospital from March 2020 to February 2021. Maternal variables like age, parity, mode of delivery, and complications were recorded. Fetal variables like period of gestation, fetal outcomes, hemoglobin, indirect bilirubin, fetal weight were noted.

Results: There were 108 cases of Rh negative pregnancy and 95 of them delivered Rh positive fetuses. Prevalence of Rh negative pregnancy was $1.68 \%$. Half of them $(51 ; 53.6 \%)$ underwent caesarean section due to obstetric indications with 20 repeat cesarean sections and $9(17.7 \%)$ cases for fetal distress. Gross perinatal death was 9; none of the patients received antepartum immunoprophylaxis; and 86 received postpartum Anti-D Rh IgG. There was only one case of proven isoimmunisation presented as hydrops fetalis in a grand multiparous woman with positive Indirect Coomb Test; and two newborn received exchanged transfusion.

Conclusion: Rhesus negative rate was $1.68 \%$ and proven isoimmunization rate was $1 \%$.

Keywords: Alloimmunization, hydrops fetalis, immunoprophylaxis, rhesus negative

\section{INTRODUCTION}

Rhesus isoimmunization may occur after fetomaternal hemorrhage during an abortion, trauma, invasive obstetric procedures or delivery and the fetal complications range from mild hemolytic anemia to hydrops fetalis. ${ }^{1,2}$

Once the mother has been sensitized, future pregnancies are at more risk for the development of the hemolytic disease of a newborn if the fetus is Rh-positive. ${ }^{3}$

The incidence of Rh incompatibility in $\mathrm{Rh}$ negative women carrying $\mathrm{Rh}$ positive fetus is about $10 \%$ of all $\mathrm{Rh}$ negative pregnancies. Sensitization however occurs only in about $5 \%$ of these cases giving an incidence of 6$7 / 1000$ of all the pregnancies. Once sensitization has occurred, the clinical and laboratory approach to evaluate and treat the disorder is difficult. ${ }^{4,5}$ Prenatal screening can be done from blood grouping, maternal Rhesus antibody (indirect Coomb's test), ultrasound-guided amniocentesis; and postnatal screening by blood grouping, indirect bilirubin, reticulocyte count and direct Coomb's test (DCT). Immunoprophylaxis with Rhesus immunoglobulin can be given at 28 weeks of gestation and within 72 hours of delivery or termination of pregnancy. ${ }^{6,7,8}$ Intrauterine transfusion and postnatal exchange transfusion may reduce perinatal mortality. 9,10

\section{METHODS}

This cross sectional study was conducted at the department of Obstetrics and Gynecology, Nobel Medical College Teaching Hospital from March 2020 to February 2021. All singleton Rhesus negative mothers were included and analysis was done only if neonate was Rhesus positive. Maternal variables like age, parity, mode of delivery, and complications were recorded. Fetal variables like period of gestation, fetal outcomes, hemoglobin, indirect bilirubin, fetal weight were noted. 


\section{RESULTS}

There were 108 cases of Rh negative pregnancy and 95 of them delivered Rh positive fetuses. Only 3 patients had antenatal check ups at this institute. Mean age of women was 24years predominantly being multigravida $56(58.9 \%)$ and $16(16.8 \%)$ women had history of miscarriage in the past. Most of them delivered at term $(85 ; 89.5 \%)$, six preterm and only four post term. Average birth weight was $2.8 \mathrm{~kg}$ (range: 1.8-3.7); and 54 were male and 41 female baby. Apgar score of neonate were above 8 in 66 $(69.5 \%)$ cases in first minute and in $75(78.9 \%)$ in five minutes. Majority of newborn were mature and neonatal morbidity rate was $14.7 \%(\mathrm{~N}=14)$. [Table1]

Table-1: Fetal outcome in Rhesus negative ( $\mathrm{N}=95)$

\begin{tabular}{lll}
\hline Fetal outcomes & $\mathrm{N}$ & $\%$ \\
\hline Mature & 73 & 76.8 \\
Neonatal anemia & 7 & 7.3 \\
Stillbirth* & 6 & 6.3 \\
Neonatal Jaundice & 3 & 3.2 \\
Premature & 3 & 3.2 \\
Neonatal death & 3 & 3.2 \\
\hline
\end{tabular}

NB. *One still birth was due to Hydrops fetalis

Commonest Fetal complication was neonatal ane$\mathrm{mia}(\mathrm{Hb}<14 \mathrm{gm} / \mathrm{dl}$ in first week of newborn) in 7 $(7.3 \%)$ and 2 severe cases $(\mathrm{Hb}<7 \mathrm{gm} / \mathrm{dl})$ underwent exchange transfusion. Main indication of neonatal admission were for blood transfusion, meconium aspiration and for phototherapy; five cases had hyperbilirubinemia of $>4 \mathrm{mg} / \mathrm{dl}$ which was managed by sun exposure and phototherapy. These five cases were one each from vacuum delivery and Caesarean section for protracted labor, and prematurity; and two cases for neonatal sepsis. [Table-2]

Table-2: Indirect serum bilirubin of newborn $(\mathrm{N}=87)$

\begin{tabular}{cc}
\hline Bilirubin $(\mathrm{mg} / \mathrm{dl})$ & Frequency \\
\hline$<2.8$ & 62 \\
$2.8-4$ & 20 \\
$>4$ & 5 \\
\hline
\end{tabular}

Gross perinatal death was 9 out of 95 with 6 stillbirths and 3 early neonatal deaths. None of the patients received antepartum immunoprophylaxis. Of the 95 patients who delivered $\mathrm{Rh}$ positive fetuses, 86 received postpartum Anti-D Rh IgG immunoprophylaxis. There was only one case of proven isoimmunisation found that presented as hydrops fetalis in grandmultiparous woman with positive Indirect Coomb Test. Direct Coombs Test performed in 87 live cases was negative. Rhesus status of fetus in perinatal death was unknown.

Among total 95 cases, there was one each case of abruptio placenta, severe preeclampsia and preg- nancy induced hypertension. One case of placentomegaly and 7 cases of oligohydramnios were noted in obstetrical ultrasonography. Half of them $(51 ; 53.6 \%)$ underwent caesarean section due to obstetric indications with 20 repeat cesarean section. Fetal distress contributed to $17.7 \%$ in 9 cases. [Table-3]

Table-3: Indication of caesarean section $(\mathrm{N}=51)$

\begin{tabular}{lcc}
\hline Indication & $\mathrm{N}$ & $\%$ \\
\hline Previous CS & 20 & 39.2 \\
Failed Induction & 11 & 21.6 \\
Fetal distress & 9 & 17.7 \\
Malpresentation & 5 & 9.8 \\
Arrest in second SOL & 3 & 5.9 \\
Placenta previa & 2 & 3.9 \\
Anhydramnios & 1 & 2 \\
\hline
\end{tabular}

Among 95 cases, 24 patients had received postpartum Anti D prophylaxis in their previous pregnancy and no significant fetal complications were seen except one case of preterm delivery among them; and three patients had past history of stillbirths which were home deliveries. 86 patients who delivered $\mathrm{Rh}$ positive fetuses received postpartum Anti D immunoprophylaxis and rest refused to take.

\section{DISCUSSION}

Incidence of Rhesus negative pregnancy was $1.68 \%$ that was similar to the studies in Nepal $(1.43 \%)^{11}$ and Bangladesh (2.4\%). ${ }^{12}$

Out of that 108 Rhesus negative pregnancies most common blood group was O $(39 ; 36.1 \%)$ followed by $\mathrm{A}(35 ; 32.4 \%)$, B $(28 ; 25.9 \%)$ and $\mathrm{AB}(6$; $5.5 \%)$. It was not much different that the study of Nagamuthu et al in 2016 that reported as B $(33.96 \%), \mathrm{O}(32.62 \%), \mathrm{A}(24.35 \%)$ and $\mathrm{AB}$ $(9.05 \%))^{13}$

Study done by Sreelatha et $\mathrm{al}^{14}$ in 2017 showed $294(56.4 \%)$ vaginal deliveries and $430(43.5 \%)$ cases of caesarean section whereas there were 44 $(46.3 \%)$ vaginal and $51(53.7 \%)$ caesarean deliveries in our study; and O-negative was the most common blood group in this study similar to ours. Multigravida were predominant in our study 56 $(58.9 \%)$ similar to the study performed by Bondagji et al. ${ }^{15}$

Isoimmunization was in one case $(1.05 \%)$ only similar to a study conducted by Lurie et al $(0.9 \%)^{16}$ in contrast to a report by Al-Ibrahim et al (7.1\%). ${ }^{17}$

Immunoprophylaxis doesn't yield expected outcome if mother is already isoimmunized like in positive indirect Coomb's Test. American College of Obstetricians and Gynecologists advises routine antibody testing before administering Rh IG. However the possibilities of isoimmunization have not 
been eliminated due to inadequate dosing of $\mathrm{Rh} \mathrm{Ig}$ and oocult fetomaternal hemorrhage before 28 weeks. The source of bleeding is often unrecognized.

In a study done by Tripathi $\mathrm{R}$ et al eight cases were associated with $\mathrm{PIH} /$ preeclampsia, one associated with polyhydramnios and three had abruptio placentae which is similar to our study but could not be an associated factor of isoimmunization. ${ }^{18}$

Indirect Coomb's test was positive in one grand multiparous woman with hydrops fetalis still birth at term similar to a study conducted by Bhati et al in western rajasthan ${ }^{19}$ Nine cases in our study didn't receive postpartum Anti D prophylaxis which may be attributed to lack of implementation of standardized and universal Anti D immunoprophylaxis. Perinatal mortality could not be associated with nine perinatal deaths as there was no diagnostic test performed to them.

\section{CONCLUSION}

Rhesus negative rate was $1.68 \%$ and proven isoimmunization rate was $1 \%$. Perinatal death could not be associated with isoimmunization due to lack of tests performed.

\section{REFERENCES}

1. Mishra R. Kriplani A, Malhotra B, Nayar B. Rhesus isoimmunisation. A Donald's Practical Obstetric Problems. 6th ed. India: Edward Arnold; 2007. p. 377.

2. Levine $\mathrm{P}$. The influence of the $\mathrm{ABO}$ system on $\mathrm{Rh}$ hemolytic disease. Hum Biol. 1958;30(1):14-28. PMID: 13513112.

3. Urbaniak SJ, Greiss MA. Rh D haemolytic disease of the fetus and the newborn. Blood Rev. 2000; 14(1):44 -61. doi: 10.1054/blre.1999.0123. PMID: 10805260.

4. Levine P. Serological Factors as Possible Causes in Spontaneous Abortions. In: Rhesus haemolytic disease. Springer, Dordrecht. 1943:75-77. https:// doi.org/10.1007/978-94-011-6138-1 6

5. Izetbegovic $\mathrm{S}$. Occurrence of $\mathrm{ABO}$ and $\mathrm{RhD}$ Incompatibility with $\mathrm{Rh}$ Negative Mothers. Mater Sociomed. 2013;25(4):255-8 doi: 10.5455/ msm.2013.25.255-258 Epub 2013 Nov 24. PMID: 24511269 ; PMCID: PMC3914752.

6. Bhutani VK, Zipursky A, Blencowe H, Khanna R, Sgro M, Ebbesen F, et al. Neonatal hyperbilirubinemia and Rhesus disease of the newborn: incidence and impairment estimates for 2010 at regional and global levels. Pediatr Res. 2013;74(Suppl 1):86100. doi: 10.1038/pr.2013.208 PMID: 24366465; PMCID: PMC3873706.
7. American College of Obstetricians and Gynecologists. ACOG Practice Bulletin No. 75. Management of alloimmunization during pregnancy. Obstet Gynecol. 2006;108(2):457-64. doi: 10.1097/00006250-200608000-00044 PMID: 16880320. Available from: https:// pubmed.ncbi.nlm.nih.gov/16880320/

8. American College of Obstetricians and Gynecologists Practice Bulletin No. 181. Prevention of Rh D Alloimmunization. Obstet Gynecol. 2017;130 (2):e57-e70. doi: 10.1097/AOG.0000000000002232. PMID: 28742673. Available from: https:// pubmed.ncbi.nlm.nih.gov/28742673/

9. Taylor JF. Sensitization of Rh-negative daughters by their Rh-positive mothers. N Engl J Med. 1967;276(10):547-51. doi: 10.1056/ NEJM196703092761004 PMID: 4960066.

10. Agarwal S, Najam R, Chowdhary HH. Prevalence of Rhesus Negative Pregnant Population at a Tertiary Care Hospital. Int J Sci Stud. 2015;2(11):67 -9

11. Singh A, Khatri R, Rana S, Malla R, Thapa S, Acharya I. High risk pregnancy and fetal outcome at Shree Birendra Hospital. J Soc Surg Nep. 2017;20(2):20-23. jssn.v20i2.24377 https://doi.org/10.3126/

12. Mondal B, Maiti S, Biswas BK, Ghosh D, Paul S. Prevalence of hemoglobinopathy, $\mathrm{ABO}$ and rhesus blood groups in rural areas of West Bengal, India. J Res Med Sci. 2012;17(8):772 -6.

13. Nagamuthu EA, Mudavath P, Prathima P, Bollipogu S. Prevalence of rhesus negativity among pregnant women. Int J Res Med Sci. 2016;4 (8):3305-9.

14. Sreelatha S, Ambastha V, Chaitra S, Satish D, Sandeep. Maternal and neonatal outcome in rhesus positive women in a tertiary care center. MOJ Womens Health. 2017;5(2):202-204. DOI: 10.15406/mojwh.2017.05.00114

15. Bondagji NS. Rhesus alloimmunization in pregnancy. Saudi Med J. 2011;32(10):1039-45.

16. Lurie S, Eliezer E, Piper I, Woliovitch I. Is antibody screening in $\mathrm{Rh}$ (D)-positive pregnant women necessary? J Mat Fet Neonat Med. 2003;14(6):404-6.

17. Al Ibrahim NA, Al Saeed AH. Red blood cell alloimmunization among Saudi pregnent women in the central province of Saudi Arabia. Kuwait Med J. 2008:116-23.

18. Tripathi R, Singh N. Maternal and perinatal outcome in $\mathrm{Rh}$ negative mothers. Int J Reprod Contracept Obstet Gynecol. 2018; 7(8):3141-6. DOI: http://dx.doi.org/10.18203/23201770.ijrcog20183306

19. Bhati I, Gulab S. Evaluation of Rh Negative pregnancies at a Tertiary Care Hospital in Western Rajasthan. IJSR. 2020; 9(6):174-6. 